\title{
Translation and validation of the Brown attention-deficit disorder scale for use in Brazil: identifying cases of attention- deficit/hyperactivity disorder among samples of substance users and non-users. Cross-cultural validation study
}

Simone Mayumi Kakubo', Mariel Mendez", Juliana Doering Silveira"', Leonardo Maringolo'v, Conrado Nitta" , Dartiu Xavier da Silveirav", Thiago Marques Fidalgo ${ }^{\mathrm{VII}}$

Universidade Federal de São Paulo (UNIFESP), São Paulo (SP), Brazil

'Medical Student, Universidade Federal de São Paulo (UNIFESP), São Paulo (SP), Brazil.

(Dorcid.org/0000-0001-8647-9443

"MPH. Public Health Professional, Mailman School of Public Health, Columbia University, New York, United States.

(D)orcid.org/0000-0003-4359-6054 "'MD. Attending Physician, Department of Psychiatry, Universidade Federal de São Paulo (UNIFESP), São Paulo (SP), Brazil.

(D)orcid.org/0000-0003-4807-7990

"MD. Attending Physician, Department of

Psychiatry, Universidade Federal de São Paulo

(UNIFESP), São Paulo (SP), Brazil.

(D)orcid.org/0000-0003-0318-2842

vMD. Attending Physician, Department of

Psychiatry, Universidade Federal de São Paulo

(UNIFESP), São Paulo (SP), Brazil.

(Dorcid.org/0000-0003-3043-872

"MD, PhD. Full Professor, Department of

Psychiatry, Universidade Federal de São Paulo

(UNIFESP), São Paulo (SP), Brazil.

(Dorcid.org/0000-0001-9264-904X

"IIMD, PhD. Affilliate Professor, Department of Psychiatry, Universidade Federal de São Paulo (UNIFESP), São Paulo (SP), Brazil.

(D)orcid.org/0000-0003-3555-5228

KEY WORDS:

Attention deficit disorder with hyperactivity. Mental disorders.

Substance-related disorders.

Psychiatry.

Comorbidity.

\begin{abstract}
BACKGROUND: The Brown Attention-Deficit Disorder Scale (BADDS) was developed as a self-report assessment that was designed to screen for presence of symptoms of attention deficit hyperactivity disorder (ADHD). The objective here was to translate and validate the adult self-report BADDS for use in Brazil. DESIGN AND SETTING: Cross-cultural validation study conducted in an addiction unit at a public university hospital.

METHODS: This study included a control group $(n=100)$ and a drug-user group $(n=100)$. Both groups included subjects aged 18 to 60 years old. The control group had no prior diagnosis of drug addiction and the drug-user group included participants with a diagnosis of addiction. Each participant answered Brazilian Portuguese translations of both the BADDS and the Adult Attention Deficit Hyperactivity Disorder Self-Report Scale (ASRS) questionnaires, in paper-and-pencil format.

RESULTS: The drug-user group scored higher than the control group on both scales. The mean scores on ASRS were 27.26 (standard deviation, SD: 11.99) and 25.85 (SD: 8.65) respectively ( $P>0.05$ ). The mean scores on BADDS were 79.56 (SD: 29.61) and 79.31 (SD: 18.09), respectively ( $P>0.05)$. Cronbach's alpha for BADDS was 0.95. BADDS presented fair sensitivity (72\% accuracy) and fair specificity ( $88 \%$ accuracy). CONCLUSION: This study provides discriminative validity evidence for use of BADDS among Brazilian adults with substance-use disorders.
\end{abstract}

\section{INTRODUCTION}

Until recently, it was believed that attention deficit hyperactivity disorder (ADHD) was exclusively a pediatric condition. ${ }^{1}$ However, current research indicates that $60 \%$ to $70 \%$ of children diagnosed with ADHD continue to manifest symptoms into adulthood. ${ }^{2}$ Persistence of symptoms of ADHD can have a pressing impact on the safety and personal relationships of patients, as well as having secondary effects in adulthood such as lost days of productivity and continual negative feedback or social and educational disadvantages. ${ }^{3}$ A recent study that used the Diagnostic and Statistical Manual of Mental Disorders-IV (DSM-IV) criteria for ADHD, which was conducted in both developed and underdeveloped countries, estimated that the worldwide prevalence of $\mathrm{ADHD}$ was 3.4\% and showed that it was higher among underdeveloped countries. ${ }^{4}$

Currently, there are no biomarkers available for diagnosing ADHD. All diagnoses require careful assessments by clinicians through interviews and appropriate classification criteria. ${ }^{5}$ Two diagnostic tools are used today to classify this disorder: DSM-5 and the International Statistical Classification of Diseases and Related Health Problems (ICD-10).

These two diagnostic tools define ADHD as a hyperkinetic disorder, a disorder characterized by inattention, hyperactivity and impulsivity with onset in childhood or adolescence. It is believed that the current diagnostic criteria (both DSM-5 and the ICD-10) are inadequate for evaluation of adults because they focus on early childhood problems and they do not fully account for developmental and maturation changes. ${ }^{6}$ The symptoms and functional impairments identified among adults for making a diagnosis of ADHD tend to be different from those observed among children. 
In cases of diagnosing children, parents and teachers play a key role in recognizing, identifying and rating the child, based on standardized evaluation scales. ${ }^{7}$ On the other hand, for adults, there is usually no one who has observed symptoms or problems with their behavior. Therefore, the diagnosis of the disorder is based upon a self-report of behaviors. Research has indicated that adolescents and adults with ADHD often underestimate their symptoms, ${ }^{8}$ thus making diagnosis much more difficult.

Many people who suffer from ADHD may also be at risk of having co-occurring psychiatric disorders or chronic illnesses. It has been estimated that more than $87 \%$ of adults with ADHD have some form of comorbidity. ${ }^{9}$ A study conducted in the United States in 2008 demonstrated that adults with ADHD had comorbidities involving anxiety (47\%), mood disorders (38\%), impulse control (20\%) and substance-use disorders (SUD) (15\%). ${ }^{10}$ The prevalence of having a comorbidity involving substance use is significantly higher among individuals with ADHD than among those without ADHD. ${ }^{11}$ It has been shown that adults with substance-use disorders are at higher risk of presenting ADHD and earlier onset of ADHD, with greater severity of SUD and chronic SUD. ${ }^{12}$ Furthermore, ADHD has been linked to lower remission rates for cigarette smoking and SUD. ${ }^{12}$ Since the impact of comorbidity between ADHD and SUD in adulthood is significant, earlier diagnosis, treatment and healthcare delivery are relevant for patient prognosis. ${ }^{12}$ This highlights the importance of studying this specific population of substance users with ADHD as a comorbidity.

In order to enhance and assist the diagnostic process for some psychiatric conditions, standardized instruments are becoming increasingly necessary. Standardized assessment instruments are widely disseminated within research and have increasingly been used as a resource for evaluating different aspects of mental health. In clinical practice, standardized instruments are critical for screening and diagnosing patients. Currently, researchers use self-report questionnaires as a critical part of screening and diagnosing patients with ADHD. Limitations exist because the screening and diagnosis tool is unavailable in other countries.

To improve the reach of the Brown Attention-Deficit Disorder Scale (BADDS) in Brazil, the aim of this study was to translate and validate it for use in Portuguese among a Brazilian sample of drug users and among a sample of people with no history of drug use.

\section{METHOD}

\section{Study design, setting and ethics}

This was a translation and cross-cultural validation study, conducted at the Federal University of São Paulo (Universidade Federal de São Paulo, UNIFESP). The ethics committee of UNIFESP approved the study (June 7, 2013; no. 17280313.2.1001.5505) All participants signed an informed consent statement.

\section{Questionnaire translation}

BADDS is a self-report questionnaire that is used for screening adults with a possible case of ADHD. ${ }^{13}$ Differently from other scales like ASRS, BADDS does not contain any DSM-5 criteria. The questions in BADDS are not driven in terms of inattention-hyperactivity-impulsivity symptoms, but instead assess functional impairment in five areas, through 40 questions. These five areas are as follows:

1. organizing and prioritizing work and activation for work;

2. focusing on tasks, sustaining this focus and shifting attention to tasks;

3. regulating alertness and sustaining effort, and the ensuing processing speed;

4. managing frustration and modulating emotions; and

5. using working memory and accessing recall.

Each question has a possible score from 1 to 4 . The higher the cluster score and overall score are, the higher the risk is that the individual has ADHD.

All individuals who complete the BADDS questionnaire are classified into three groups: i) possible, but unlikely to have ADHD, if the score is less than 40; ii) possible, but unconfirmed ADHD, if the score is between 40 and 54; and iii) highly likely but unconfirmed ADHD, if the score is above 55.

A 2008 study demonstrated that BADDS was more reliable than were other instruments that were based on the DSM-IV criteria. ${ }^{14}$ The information provided by the patient via this self-report questionnaire and through information from someone close to the patient is more accurate for assessing ADHD symptoms than is use of the DMS- 5 criteria.

The paper-and-pencil format of BADDS was translated into Portuguese. The translation was conducted using a two-step procedure, known as the back-translation method, as recommended by Brislin (1973) and by Smit (2006). ${ }^{15,16}$ According to these authors, two bilingual translators are required in order to come to a consensus regarding any translational difficulties or discrepancies. ${ }^{15,16}$ In our case, a bilingual psychiatrist first translated the items from English to Portuguese, followed by back-translation into English conducted by a linguist. The discrepancies between the two versions were resolved by reaching a consensus between the two bilingual professionals.

ASRS is currently the most accepted and most widely used self-report questionnaire for screening for ADHD symptoms. ${ }^{17}$ The questionnaire asks directly about the existence of inattention-hyperactivity-impulsivity symptoms, in the way in which these are presented in the DSM- 5 criteria. It consists of 18 questions, with scores for each question ranging from 0 to 4 . Zero means that no symptoms were present within the last six months, while 4 indicates that all symptoms were present within the last six months. The composite scores of this questionnaire, similarly to BADDS, classifies patients 
into categories depending on the risk of ADHD. Patients with scores between 0 and 16 are considered to be individuals with an unlikely risk of having $\mathrm{ADHD}$; patients with scores between 17 and 23 are considered to be individuals with a likely chance of having ADHD; and finally, individuals with scores of 24 and over are considered to present a high likelihood of having ADHD.

ASRS was chosen as the gold standard for this study. The main reason for this choice was that the Addiction Unit did not have enough trained psychiatrists to perform a complete ADHD diagnosis on these 100 subjects. It is important to state that this unit is not specifically designed for research purposes and that this evaluation would imply a significant increase in the psychiatrists' workload.

\section{Participants}

The validation study sample consisted of two groups. One group (control group) consisted of a convenience sample of 100 students from UNIFESP, in accordance with the following inclusion criteria: i) between the ages of 18 and 60 years; ii) either female or male; iii) literate, independent of education level, socioeconomic level or ethnicity; and iv) no prior diagnosis of psychiatric conditions or drug addiction (according to self-report).

The second group (drug users) comprised 100 adults who were currently attending an outpatient facility, the Addiction Unit of UNIFESP (through the Guidance and Attendance Program for Substance Dependents; Programa de Orientação e Atendimento a Dependentes, PROAD). At this facility, patients participate in weekly group therapy sessions and are individually evaluated by a psychiatrist at least once a month. This trained psychiatrist is responsible for making the diagnosis of drug dependence, using the DSM- 5 criteria. Individual sessions with a psychologist may form part of the treatment, depending on the needs of each patient. For our second group, the same inclusion criteria were used, with the addition that all patients had a diagnosis of substance dependence, which had been assessed and diagnosed by a psychiatrist in accordance with the DSM- 5 criteria. All substances except tobacco were included in the assessment.

All participants in both groups answered two self-report questionnaires: BADDS and the Adult ADHD Self-Report Scale (ASRS). Aside from age, gender and psychiatric diagnosis, no other sociodemographic or clinical information was collected.

\section{Statistical analysis}

The total scores on both scales were tested in order to check for normal distribution, which was confirmed. Chi-square tests were used to analyze categorical data, while t tests were used to analyze parametric continuous variables. The internal consistency of BADDS was measured by means of the Cronbach's alpha method. Alpha was computed by correlating the score for each scale item with the total score for each individual observation, and then making comparisons with the variance for all individual item scores. ${ }^{18}$
The participants' scores were compared using the means that were obtained through the two questionnaires, to determine criteria for concurrent and discriminant validation measurements for BADDS. Given the scores from each questionnaire, several cutoff points were verified for sensitivity and specificity, in increments of 10 (instead of the usual one-by-one increments of scores that are used for most of the instruments available).

To analyze cutoff points, the receiver operating characteristic (ROC) curve was used. The statistical significance level was taken to be 0.05 . The statistical analysis software Statistical Package for the Social Sciences (SPSS 22.0) for Windows was used.

\section{RESULTS}

Within the drug-user group, men comprised $87 \%$ of the sample, whereas in the control group, men represented $47 \%$ of the total sample. The drug-user group scored higher than the control group in both ADHD instruments. The mean score from the ASRS questionnaire in the drug-user group was 27.26 (SD: 11.99), compared with 25.85 (SD: 8.65) in the control group $(\mathrm{P}>0.05)$. The mean scores from the BADDS questionnaire were 79.56 (SD: 29.61) and 79.31 (SD: 18.09), respectively ( $\mathrm{P}>0.05)$. Cronbach's alpha from BADDS was 0.95 .

Table 1 summarizes the results from the ROC analysis (Figure 1). The optimum cutoff score was 50, as shown in Table 1. Scores below 50 indicate a negative diagnosis for ADHD, whereas scores of 51 and over indicate a positive diagnosis. Using this threshold, the substance abuse scale detected true positives (sensitivity) with $72 \%$ accuracy and true negatives (specificity) with $88 \%$ accuracy. For both groups, the area under the curve was 0.891 .

\section{DISCUSSION}

This study demonstrated that BADDS, a tool for diagnosing ADHD among adults, has high internal consistency and differentiates possible cases of ADHD among people with concurrent substance use and people without a psychiatric diagnosis. The scale has fair sensitivity and specificity.

These results encourage use of BADDS for identifying possible ADHD cases, both in clinical practice and in research. Screening for ADHD using this scale enables greater agility in reaching diagnostic confirmation of ADHD. Moreover, this tool results in the following:

1. higher quality for the service, given that a standard is created for diagnostic investigation;

2. improvement of adherence to treatment, since patients can track their progress through reductions in the scores; and

3. greater focus of the available resources on individuals who are accurately screened positive, so that they can be evaluated by a psychiatrist or a psychologist. 
Table 1. Cutoff points compared between control group, addiction unit group (treated at PROAD) and both groups together (total)

\begin{tabular}{|c|c|c|c|c|c|c|}
\hline \multirow{2}{*}{ Cutoffa $^{a}$} & \multicolumn{2}{|c|}{ Total $^{b}$} & \multicolumn{2}{|c|}{ PROAD } & \multicolumn{2}{|c|}{ Control group ${ }^{d}$} \\
\hline & Sensitivity & Specificity & Sensitivity & Specificity & Sensitivity & Specificity \\
\hline 20 & 0.985 & 0.225 & 0.985 & 0.322 & 0.985 & 0.129 \\
\hline 40 & 0.869 & 0.693 & 0.956 & 0.709 & 0.782 & 0.677 \\
\hline 50 & 0.724 & 0.887 & 0.869 & 0.935 & 0.579 & 0.838 \\
\hline 60 & 0.492 & 0.951 & 0.652 & 0.967 & 0.333 & 0.935 \\
\hline 90 & 0.137 & 1 & 0.217 & 1 & 0.057 & 1 \\
\hline 100 & 0.050 & 1 & 0.101 & 1 & 0 & 1 \\
\hline 110 & 0.028 & 1 & 0.057 & 1 & 0 & 1 \\
\hline 120 & 0.014 & 1 & 0.028 & 1 & 0 & 1 \\
\hline$>120$ & 0 & 1 & 0 & 1 & 0 & 1 \\
\hline
\end{tabular}

${ }^{a}$ Cutoff points as presented in the method section; ${ }^{b}$ Total = scores of the PROAD and control groups together; ${ }^{C P R O A D}=$ scores of the addiction unit group;

${ }^{\mathrm{d}}$ Control group $=$ scores of the control group.

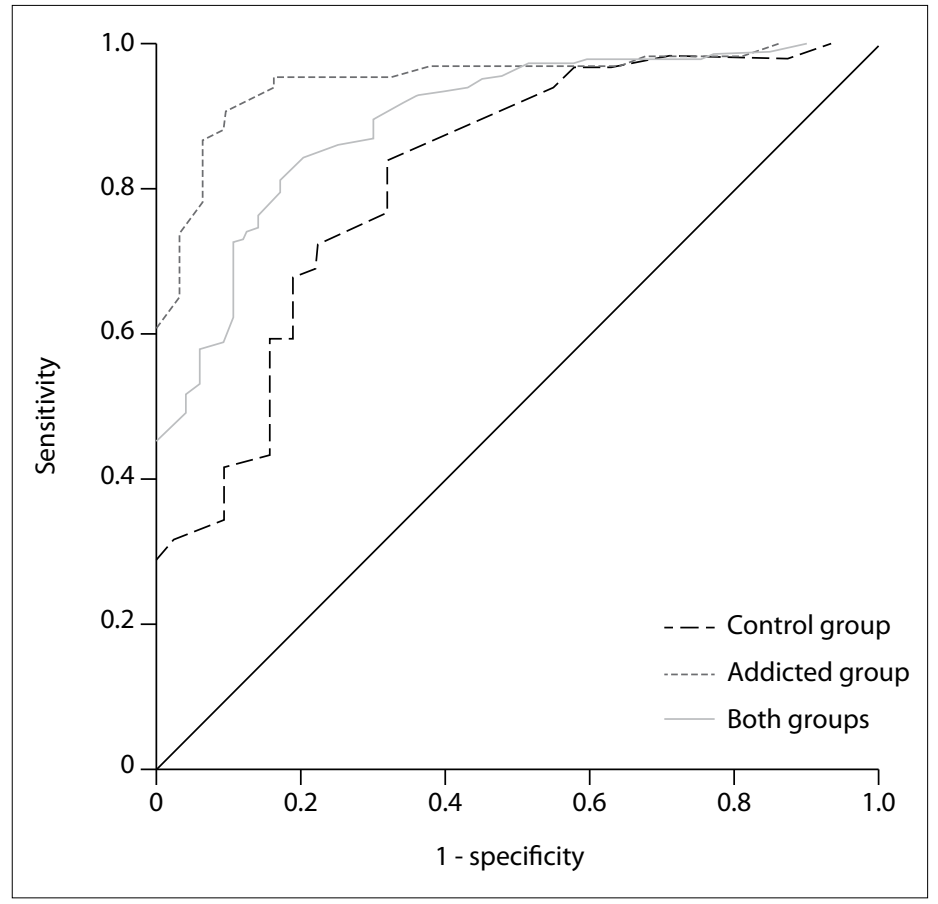

Figure 1. Receiver operating characteristic curve of the control group $(n=100)$, addicted group $(n=100)$ and both groups together $(n=200)$.

In this context, it is essential to develop and validate these important tools, not only to improve the diagnostic process, but also to allocate resources where needed.

Once validated, the BADDS scale can become a screening tool that could improve psychiatric care and provide resources for those who truly are ADHD-positive. The self-report format, the non-medical language and the fact that the questions do not examine only the presence of symptoms make the Brown Attention-Deficit Disorder Scale a valuable instrument for use by any healthcare professional who wants to optimize ADHD healthcare services (Annex 1).
Diagnosing psychiatric disorders is complex, and this is even more so when they are associated with other psychiatric comorbidities, as is the case with ADHD. The lack of biomarkers to identify psychiatric conditions makes validation tools necessary, to minimize diagnostic difficulties.

Screening instruments are useful and increase the quality of healthcare services. Validated screening tools provide cost-effectiveness strategies, reinforce diagnostic accuracy and allow exploration of different aspects of mental health. In addition, they adds to the body of knowledge of overall mental health examination and care.

Since the demand for mental health facilities is greater than the number of care services available in Brazil, validation of the BADDS questionnaire provides the possibility of extrapolating the sphere of psychiatric consultation offices and could be a way to reduce the gap in mental health facilities. It could reduce the burden on mental health facilities, while simultaneously correctly identifying cases of adults living with ADHD.

\section{Limitations}

Some limitations of the present study need to be noted. Because a self-report questionnaire was used, rather than psychiatric interviews, the questions were subject to interpretation by the participants and to possible information bias. Moreover, a psychiatric interview should be the gold standard, but this was not possible because of limitations to the capacity of our facility. In addition, this was a cross-sectional survey and therefore associations do not imply causation. Lastly, although sensitivity and specificity are characteristics of each test, positive and negative predictive values depend on the prevalence of the condition studied within a given sample. Therefore, in populations with low prevalence of ADHD, the positive predictive value tends to be low and the negative predictive values tend to be high. This means that, although the findings through 
an instrument might rule out a diagnosis of ADHD, there is a high chance that any positive results will in fact be false positives.

\section{CONCLUSION}

In summary, this study conducted on a Brazilian sample demonstrated that BADDS has discriminative validity for making diagnoses of ADHD. The ROC curve analyses showed the usefulness of BADDS for detecting adults who need ADHD treatment, particularly among those with substance-use disorders.

\section{REFERENCES}

1. Searight HR, Burke JM, Rottnek F. Adult ADHD: evaluation and treatment in family medicine. Am Fam Physician. 2000;62(9):2077-86, 2091-2. PMID: 11087189.

2. Barkley RA, Fischer M, Smallish L, Fletcher K. The persistence of attentiondeficit/hyperactivity disorder into young adulthood as a functional of reporting source and definition of disorder. J Abnorm Psychol. 2002;111(2):279-89. PMID: 12003449.

3. Barkley RA. ADHD: Long-term course adult outcome and comorbid disorders. In: NIH Consensus Development Conference on Diagnosis and Treatment of Attention Deficit Hyperactivity Disorder, 1998 November 16-18. Maryland: National Institutes of Health Bethesda; 1998. p. 57-60. Available from: https://consensus.nih.gov/1998/1998attentiondeficit hyperactivitydisorder110program.pdf. Accessed in 2017 (Dec 12).

4. Fayyad J, De Graaf R, Kessler R, et al. Cross-national prevalence and correlates of adult attention-deficit hyperactivity disorder. Br J Psychiatry. 2007;190:402-9. doi: 10.1192/bjp.bp.106.034389.

5. Remschmidt H; Global ADHD Working Group. Global consensus on ADHD/HKD. Eur Child Adolesc Psychiatry. 2005;14(3):127-37. doi: 10.1007/s00787-005-0439-x.

6. McGough JJ, Barkley RA. Diagnostic controversies in adult attention deficit hyperactivity disorder. Am J Psychiatry. 2004;161(11):1948-56. doi: 10.1176/appi.ajp.161.11.1948.

7. Power TJ, Doherty BJ, Panichelli-Mindel SM, et al. The predictive validity of parent and teacher reports of ADHD symptoms. Journal of Psychopathology and Behavioral Assessment. 1998;20(1):57-81. Available from: https://libres.uncg.edu/ir/uncg/f/A_Anastopoulos_ Predictive_1998.pdf. Accessed in 2017 (Dec 12).

8. Smith BH, Pelham WE Jr, Gnagy E, Molina B, Evans S. The reliability, validity, and unique contributions of self-report by adolescents receiving treatment for attention-deficit/hyperactivity disorder. J Consult Clin Psychol. 2000;68(3):489-99. PMID: 10883565.

9. McGough JJ, Smalley SL, McCracken JT, et al. Psychiatric comorbidity in adult attention deficit hyperactivity disorder: findings from multiplex families. Am J Psychiatry. 2005;162(9):1621-7. doi: 10.1176/appi.ajp.162.9.1621.

10. Kessler RC, Adler LA, Barkley RA, et al. The prevalence and correlates of adult ADHD in the United States: results from National Comorbidity Survey Replication. Am J Psychiatry. 2006;163(4):716-23. doi: 10.1176/ ajp.2006.163.4.716.
11. Wilens TE, Biederman J, Mick E, Faraone SV, SpencerT. Attention deficit hyperactivity disorder (ADHD) is associated with early onset substance use disorder. J Nerv Ment Dis. 1997;185(8):475-82. PMID: 9284860.

12. Wilens TE, Morrison NR. The intersection of attention-deficit/hyperactivity disorder and substance abuse. Curr Opin Psychiatry. 2011;24(4):280-5. doi: 10.1097/YCO.0b013e328345c956.

13. Brown Attention-Deficit Disorder Scales: Manual. San Antonio, TX: The Psychological Corporation; 1996.

14. Sandra Kooji JJ, Mariie Boonstra A, Swinkels SH, et al. Reliability, validity, and utility of instrumental for self-report and informant report concerning symptoms of ADHD in adult patients. J Atten Disord. 2008;11(4)445-58. doi: 10.1177/1087054707299367.

15. Brislin R, Lonner W, Thorndike R. Cross-cultural research methods. New York: John Wiley \& Sons; 1973.

16. Smit J, van den Berg CE, Bekker LG, Seedat S, Stein DJ. Translation and cross-cultural adaptation of a mental health battery in an African setting. Afr Health Sci. 2006;6(4):215-22. doi: 10.5555/afhs.2006.6.4.215.

17. Kessler RC, Adler LA, Gruber MJ, et al. Validity of the World Health Organization Adult ADHD Self-Report Scale (ASRS) Screener in a representative sample of health plan members. Int J Methods Psychiatr Res. 2007;16(2):52-65. doi: 10.1002/mpr.208.

18. Heo M, Kim N, Faith MS. Statistical power as a function of Cronbach alpha of instrument questionnaire items. BMC Med Res Methodol. 2015;15:86. doi: 10.1186/s12874-015-0070-6.

Sources of funding: This study was funded by Conselho Nacional de Desenvolvimento Científico e Tecnológico (CNPq) under number $122507 / 2014-2$

\section{Conflicts of interest: None}

Date of first submission: July 19, 2017

Last received: November 30, 2017

Accepted: December 12, 2017

\section{Address for correspondence:}

Thiago Marques Fidalgo

Universidade Federal de São Paulo (UNIFESP)

Av. Professor Ascendino Reis, 763

Vila Clementino - São Paulo (SP) — Brasil

CEP 04027-000

Tel. (+55 11) 5579-1543

E-mail: marquesfidalgo@yahoo.com.br 
Annex 1. Brown Attention-Deficit Disorder Scale (BADDS) and Adult Self-Report Scale (ASRS) for ADHD BADDS

1. Ouve e tenta prestar atenção em reuniões, aulas ou conversas, mas a mente frequentemente se dispersa; perde informações de importância?
a. Nunca
b. Uma vez por semana ou menos
c. Duas vezes por semana
d. Quase diariamente

2. Sente muita dificuldade para iniciar tarefas (exemplo: atividades burocráticas ou realizar contatos com outras pessoas)?
a. Nunca
b. Uma vez por semana ou menos
c. Duas vezes por semana
d. Quase diariamente

3. Sente-se demasiadamente estressado ou sobrecarregado com tarefas que deveriam ser manejáveis (exemplo: "de jeito nenhum consigo fazer tudo isso agora, isto está fora do meu alcance" - apesar da situação não ser tão ruim assim)?
a. Nunca
b. Uma vez por semana ou menos
c. Duas vezes por semana
d. Quase diariamente

4. "Sai do ar" involuntária e frequentemente durante leituras necessárias; pensa em coisas que não têm nada a ver com o que está sendo lido?
a. Nunca
b. Uma vez por semana ou menos
c. Duas vezes por semana
d. Quase diariamente

5. Perde o foco com facilidade; inicia uma tarefa e em seguida muda para algo menos importante?
a. Nunca
b. Uma vez por semana ou menos
c. Duas vezes por semana
d. Quase diariamente

6. Perde o fio da meada do que acabou de ser lido e precisa retomar a leitura; compreende as palavras, mas simplesmente não guarda o que foi lido?

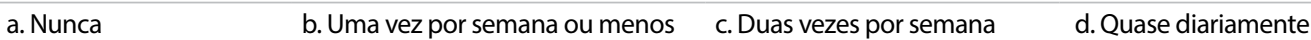

7.É muito esquecido com relação ao que foi dito, feito ou ouvido nas últimas 24 horas?

a. Nunca b. Uma vez por semana ou menos c. Duas vezes por semana

d. Quase diariamente

8. Lembra-se de alguns detalhes das leituras, mas não consegue assimilar a ideia central?
a. Nunca
b. Uma vez por semana ou menos
c. Duas vezes por semana
d. Quase diariamente

9. Frustra-se com facilidade e é muito impaciente?
a. Nunca
b. Uma vez por semana ou menos
c. Duas vezes por semana
d. Quase diariamente

10. Fica confuso quando recebe muita coisa para fazer, tem dificuldade para estabelecer prioridades, organizar-se e começar?
a. Nunca
b. Uma vez por semana ou menos
c. Duas vezes por semana
d. Quase diariamente

11. Adia os afazeres, frequentemente deixa-os de lado (exemplo: "farei depois" ou "farei amanhä")?
a. Nunca
b. Uma vez por semana ou menos
c. Duas vezes por semana
d. Quase diariamente

12. Sente-se sonolento ou cansado durante o dia, mesmo após uma noite satisfatória de sono?
a. Nunca
b. Uma vez por semana ou menos
c. Duas vezes por semana
d. Quase diariamente

13. É desorganizado; tem muita dificuldade para monitorar planos, dinheiro ou tempo?
a. Nunca
b. Uma vez por semana ou menos
c. Duas vezes por semana
d. Quase diariamente

14. Não consegue completar tarefas no tempo planejado; precisa de um tempo extra para concluir satisfatoriamente?
a. Nunca
b. Uma vez por semana ou menos
c. Duas vezes por semana
d. Quase diariamente

15. Planeja fazer coisas, mas esquece (exemplo: desligar aparelhos, comprar coisas na loja, retornar ligações telefônicas, ir a compromissos, pagar contas, cumprir deveres)?
a. Nunca
b. Uma vez por semana ou menos
c. Duas vezes por semana
d. Quase diariamente

16. Critica-se ou os outros o criticam por ser preguiçoso?
a. Nunca
b. Uma vez por semana ou menos
c. Duas vezes por semana
d. Quase diariamente

17. A qualidade de seus trabalhos é inconsistente; o seu desempenho é completamente flutuante; esquiva-se das tarefas a menos que esteja sob pressão?
a. Nunca
b. Uma vez por semana ou menos
c. Duas vezes por semana
d. Quase diariamente

18. É sensível a críticas; ressente-se profundamente ou por um tempo prolongado; torna-se excessivamente defensivo?
a. Nunca
b. Uma vez por semana ou menos c. Duas vezes por semana
d. Quase diariamente

19. Demora para reagir ou ter iniciativa; é lento ou faz tudo devagar; não se atira de imediato para as atividades; demora para responder a perguntas ou se aprontar para algo?
a. Nunca
b. Uma vez por semana ou menos
c. Duas vezes por semana
d. Quase diariamente

20. Irrita-se com facilidade; é "pavio curto" e tem ataques repentinos de raiva?
a. Nunca
b. Uma vez por semana ou menos
c. Duas vezes por semana
d. Quase diariamente

21. É muito rígido ou perfeccionista (tem que fazer as coisas sempre do mesmo jeito, é "cricri")?
a. Nunca
b. Uma vez por semana ou menos
c. Duas vezes por semana
d. Quase diariamente

22. É criticado por não alcançar todo o seu potencial (ex., "poderia fazer muito melhor se ao menos... me esforçasse mais ou trabalhasse mais consistentemente")?
a. Nunca
b. Uma vez por semana ou menos
c. Duas vezes por semana
d. Quase diariamente

23. Pega-se "sonhando acordado" ou preocupado com os próprios pensamentos?
a. Nunca
b. Uma vez por semana ou menos
c. Duas vezes por semana
d. Quase diariamente

24. Tem dificuldade para expressar raiva de maneira adequada; não consegue se impor?
a. Nunca
b. Uma vez por semana ou menos
c. Duas vezes por semana
d. Quase diariamente

25. Perde o fio da meada e não vai até o final; seu esforço se dissipa rapidamente?
a. Nunca
b. Uma vez por semana ou menos
c. Duas vezes por semana
d. Quase diariamente 
Annex. Continuation

\section{BADDS}

26. Dispersa-se com facilidade por barulhos ou atividades do ambiente; precisa verificar qualquer outra coisa que esteja acontecendo?
a. Nunca
b. Uma vez por semana ou menos
c. Duas vezes por semana
d. Quase diariamente

27. Tem muita dificuldade para acordar de manhã; acha extremamente difícil levantar-se da cama e começar a fazer as coisas?
a. Nunca
b. Uma vez por semana ou menos c. Duas vezes por semana
d. Quase diariamente

28. Na escrita, necessita repetidamente apagar, rasurar ou recomeçar devido a erros pequenos?
a. Nunca
b. Uma vez por semana ou menos
c. Duas vezes por semana
d. Quase diariamente

29. Com frequência se sente desencorajado, triste ou para baixo?
a. Nunca
b. Uma vez por semana ou menos
c. Duas vezes por semana
d. Quase diariamente

30. Tende a se isolar de seus pares, é reservado e tímido; não se associa muito com amigos da mesma idade?
a. Nunca
b. Uma vez por semana ou menos
c. Duas vezes por semana
d. Quase diariamente

31. Parece apático ou desmotivado (os outros pensam que não se importa absolutamente com o seu trabalho)?
a. Nunca
b. Uma vez por semana ou menos
c. Duas vezes por semana
d. Quase diariamente

32. Fica com olhar fixo e distante; parece estar no "mundo da lua"?
a. Nunca
b. Uma vez por semana ou menos
c. Duas vezes por semana
d. Quase diariamente

33. Na escrita, frequentemente deixa de fora palavras ou letras?
a. Nunca
b. Uma vez por semana ou menos
c. Duas vezes por semana
d. Quase diariamente

34. Apresenta caligrafia desleixada e difícil de ler?
a. Nunca
b. Uma vez por semana ou menos c. Duas vezes por semana
d. Quase diariamente

35. Esquece-se de levar - ou não lembra onde deixou - itens importantes como chaves, lápis, contas e documentos ("Sei que está aqui em algum lugar; apenas não consigo encontrar agora...")?
a. Nunca
b. Uma vez por semana ou menos
c. Duas vezes por semana
d. Quase diariamente

36. Parece não estar ouvindo ou recebe reclamações dos outros a respeito?
a. Nunca
b. Uma vez por semana ou menos
c. Duas vezes por semana
d. Quase diariamente

37. Os outros precisam lembrá-lo de começar ou de manter-se engajado em tarefas que precisam feitas?
a. Nunca
b. Uma vez por semana ou menos
c. Duas vezes por semana
d. Quase diariamente

38. Apresenta dificuldade de memorização (ex., nomes, data, informações do trabalho)?
a. Nunca
b. Uma vez por semana ou menos
c. Duas vezes por semana
d. Quase diariamente

39. Entende mal as orientações para preencher formulários, realizar tarefas etc.?
a. Nunca
b. Uma vez por semana ou menos
c. Duas vezes por semana
d. Quase diariamente

40. Inicia atividades (exemplo: papelada, afazeres), mas não finaliza?
a. Nunca
b. Uma vez por semana ou menos
c. Duas vezes por semana
d. Quase diariamente

\section{ASRS}

1. Com que frequência você comete erros por falta de atenção quando tem de trabalhar num projeto chato ou difícil?
a. Nunca
b. Raramente
c. Algumas vezes
d. Frequentemente
e. Muito frequentemente

2. Com que frequência você tem dificuldade para manter a atenção quando está fazendo um trabalho chato ou repetitivo?
a. Nunca
b. Raramente
c. Algumas vezes
d. Frequentemente
e. Muito frequentemente

3. Com que frequência você tem dificuldade para se concentrar no que as pessoas dizem, mesmo quando elas estão falando diretamente com você?
a. Nunca
b. Raramente
c. Algumas vezes
d. Frequentemente
e. Muito frequentemente

4. Com que frequência você deixa um projeto pela metade depois de já ter feito as partes mais difíceis?
a. Nunca
b. Raramente
c. Algumas vezes
d. Frequentemente
e. Muito frequentemente

5. Com que frequência você tem dificuldade para fazer um trabalho que exige organização?
a. Nunca
b. Raramente
c. Algumas vezes
d. Frequentemente
e. Muito frequentemente

6. Quando você precisa fazer algo que exige muita concentração, com que frequência você evita ou adia o início?
a. Nunca
b. Raramente
c. Algumas vezes
d. Frequentemente
e. Muito frequentemente

7. Com que frequência você coloca as coisas fora do lugar ou tem de dificuldade de encontrar as coisas em casa ou no trabalho?
a. Nunca
b. Raramente
c. Algumas vezes
d. Frequentemente
e. Muito frequentemente

8. Com que frequência você se distrai com atividades ou barulho a sua volta?
a. Nunca
b. Raramente
c. Algumas vezes
d. Frequentemente
e. Muito frequentemente

9. Com que frequência você tem dificuldade para lembrar de compromissos ou obrigações?
a. Nunca
b. Raramente
c. Algumas vezes
d. Frequentemente
e. Muito frequentemente

10. Com que frequência você fica se mexendo na cadeira ou balançando as mãos ou os pés quando precisa ficar sentado (a) por muito tempo?
a. Nunca
b. Raramente
c. Algumas vezes
d. Frequentemente
e. Muito frequentemente

11. Com que frequência você se levanta da cadeira em reuniões ou em outras situações onde deveria ficar sentado (a)?
a. Nunca
b. Raramente
c. Algumas vezes
d. Frequentemente
e. Muito frequentemente 
Annex. Continuation

ASRS

12. Com que frequência você se sente inquieto (a) ou agitado (a)?
a. Nunca
b. Raramente
c. Algumas vezes
d. Frequentemente
e. Muito frequentemente

13. Com que frequência você tem dificuldade para sossegar e relaxar quando tem tempo livre para você?
a. Nunca
b. Raramente
c. Algumas vezes
d. Frequentemente
e. Muito frequentemente

14. Com que frequência você se sente ativo (a) demais e necessitando fazer coisas, como se estivesse "com um motor ligado"?
a. Nunca
b. Raramente
c. Algumas vezes
d. Frequentemente
e. Muito frequentemente

15. Com que frequência você se pega falando demais em situações sociais?
a. Nunca
b. Raramente
c. Algumas vezes
d. Frequentemente
16. Quando você está conversando, com que frequência você se pega terminando as frases das pessoas antes delas?

e. Muito frequentemente
a. Nunca
b. Raramente
c. Algumas vezes
17. Com que frequência você tem dificuldade para esperar nas situações onde cada um tem a sua vez?

d. Frequentemente

e. Muito frequentemente

a. Nunca

b. Raramente

c. Algumas vezes

d. Frequentemente

e. Muito frequentemente

18. Com que frequência você interrompe os outros quando eles estão ocupados?

a. Nunca

b. Raramente

c. Algumas vezes

d. Frequentemente

e. Muito frequentemente 